\title{
Література:
}

1. Бару М. И. Оценочные понятия в трудовом законодательстве. Советское государство и право.1970. № 7. С. 104-108.

2. Богданович С.П. Оценочные понятия в вещном и обязательственном праве : автореф. дис. ... канд. юрид. наук : 12.00.03. Краснодар, 2012. $28 \mathrm{c}$.

3. Цивільний кодекс України від 16.01.2003. № 435-IV. Дата оновлення: 28.10.2021. URL: https://zakon.rada.gov.ua/laws/show/ 435-15\#Text (дата звернення: 24.12.2021).

DOI https://doi.org/10.30525/978-9934-26-179-4-13

\section{TECHNOLOGY TRANSFER AGREEMENTS IN THE SYSTEM OF INTELLECTUAL PROPERTY AGREEMENTS}

\author{
Dmytrenko V. V. \\ Candidate of Science of Law,
}

Senior Lecturer at the Department of Intellectual Property and Private Law

National Technical University of Ukraine

"Igor Sikorsky Kyiv Polytechnic Institute"

Kyiv, Ukraine

In the field of intellectual property, such terms as "technology transfer" and "technology transfer agreements" are often used. The phrase "technology transfer agreements" is of certain interest, since such agreements are not mentioned in the Civil Code and Commercial Code of Ukraine, in any special laws of Ukraine related to intellectual property. Instead, in the Law of Ukraine "On State Regulation of Activity in the Sphere of Transfer of Technologies", Section IV is dedicated to such agreements. Article 1 of this Law [1] states that under technology transfer agreements, people transfer economic rights to a technology or its components fully or partially, while the object of technology may be objects of intellectual property rights. Article 20 of this Law [1] stipulates about the conclusion of intellectual property rights agreements when a technology is transferred, including the terms for entering into technology transfer agreements prescribed by law. It is also stipulated that along with the technology transfer agreements, the following agreements may be concluded: warranty agreements (for the persons transferring the technology, 
to achieve economic performance and production using the technology), confidentiality agreements, agreements to perform a set of works for the use of technology and maintenance of equipment. Chapter 75 of the Civil Code of Ukraine (hereinafter referred to as the CC of Ukraine) [2] - "Disposal of Intellectual Property Rights" stipulates about the license, license agreement, agreement to transfer exclusive intellectual property rights, agreement for creating (by order) and using an intellectual property right object. However, this list is not limited, since in the field of intellectual property, people may also conclude other agreements whose terms do not contradict applicable laws. The structure of a technology transfer agreement resembles a commercial concession agreement, under which the following is provided: a set of intellectual property rights, business reputation, commercial experience. But under technology transfer agreements, business reputation is usually not transferred. The commercial concession agreement is stipulated in Chapter 76 of the Civil Code of Ukraine.

Can a technology transfer agreement be considered an intellectual property agreement? What objects of intellectual property rights can be the objects of technology and its components? What contractual structures for the disposal of intellectual property rights can be used in technology transfer agreements?

Article 1 of the Law of Ukraine "On State Regulation of Activity in the Sphere of Transfer of Technologies" provides an inexhaustible list of the objects of intellectual property rights, which can be objects of technology, including inventions, useful models, copyrights, trade secrets, know-how. Article 19 of the same Law [1] states that trademarks and trade names may be transferred. It is clear that trademarks and trade names cannot be objects of technology, but the possibility of transferring them with technology is stipulated. Any scientific, technical works, software may seem to be part of technology, yet they are objects of copyright. There are doubts about attributing copyright objects to technology objects due to the fact that copyright does not protect the essence of the result. Protection of such results by copyright alone seems insufficient. We believe that the objects of technology can also be combinations of semiconductor products, plant varieties, animal breeds. No intellectual property agreements are concluded regarding any scientific discovery or geographical indication, and therefore no technology transfer agreements may be concluded regarding these objects.

We believe that among the intellectual property agreements stipulated in the CC of Ukraine, for technology transfer, one can apply exclusive intellectual property rights transfer agreements, under which intellectual property rights to a technology are irrevocably alienated, and a license agreement under which the technology is allowed to be used. The license is 
not an agreement. But a certain type of license is always granted under a license agreement. The use of an agreement for creating (by order) and using an intellectual property right object for technology transfer seems questionable, since such an agreement is aimed to create copyright objects, while the objects of technology can usually be the results of technical creativity. However, we believe that technology transfer can be made under a commercial concession agreement. Creating a technology can be ordered under an agreement for performing scientific-research or researchdevelopment and technological works or under another agreement which is not clearly prescribed by the applicable laws, but its terms should correspond to its basic principles.

The question arises: why single out specific "technology transfer agreements", if certain structures from intellectual property rights disposal agreements are going to be used in them? This is primarily due to the specifics of technology transfer, since this process requires applying a certain contractual form from Chapter 75 of the Civil Code of Ukraine, and the transfer of equipment, scientific-technical and technological documents is also important.

Thus, we consider technology transfer agreements to be mixed agreements in the field of intellectual property, since they represent a certain contractual structure in the field of intellectual property defined in the $\mathrm{CC}$ of Ukraine and also contain elements of other agreements necessary to ensure proper technology transfer process.

\section{References:}

1. Про державне регулювання діяльності у сфері трансферу технологій: Закон України від 14 вересня 2006 р. № 143-V. Дата оновлення: 16 жовтня 2020 p. URL: https://zakon.rada.gov.ua/laws/ show/143-16\#Text (дата звернення: 23 грудня 2021 p.).

2. Цивільний кодекс України: Закон України від 16 січня 2003 p. № 435-IV. Дата оновлення: 19 грудня 2021 p. URL: https://zakon.rada.gov.ua/laws/show/435-15\#Text (дата звернення: 23 грудня 2021 р.). 